\title{
INTERLOCUTORY DEFENDANT APPEALS UNDER SECTION 75(2)(c) OF THE ILLINOIS CIVIL PRACTICE ACT
}

A recent application of Section 75(2)(c) of the Illinois Civil Practice Act 1 resulted in a defendant's interlocutory appeal to the Supreme Court of Illinois under the guise of a final order. ${ }^{2}$ The section gives a party whose judgment in the trial court has been reversed and remanded by the appellate court the right to make the judgment final by moving to strike the remanding portion of the judgment and by filing an affidavit that he is unable to adduce other evidence and that he waives his right to a new trial. The purpose of the section is to "streamline litigation and prevent costly and burdensome retrials of cases which may later be found to be predicated upon bad law...."3 By allowing a party to make final an otherwise interlocutory order, 4 the statute permits a litigant who has had his judgment reversed by an appellate court to avoid unnecessary costs and delay by immediately obtaining the right to request a

1 ILL. Rev. Stat. ch. 110, §75(2)(c) (1959): "In any case heard and determined in the trial court upon actual trial in which the Appellate Court upon appeal from the final judgment or decree entered in the cause in the trial court reverses the judgment or decree and remands the cause for a new trial or hearing, and in which the party in whose favor the trial court's judgment or decree was rendered presents to and files with the Appellate Court an affidavit stating that he will be unable on a future trial or hearing to adduce other or additional evidence, facts or circumstances than were adduced in the trial court and expressly waiving the right to a new trial or hearing and consenting and requesting that the portion of the judgment of the Appellate Court remanding the cause for new trial or hearing be deleted and stricken from the judgment of the Appellate Court, then that court upon motion shall amend its judgment by striking out the portion thereof remanding the cause for new trial or hearing. Thereupon it is competent for the Supreme Court to grant leave to appeal from such final judgment of reversal for its review. ..."

2 John v. Tribune Co., Civil No. 36450, Ill. Sup. Ct., Jan. 23, 1962, petition for rehearing filed. In an action for libel the trial court sustained a motion to dismiss the complaint. The appellate court reversed and remanded. 19 Ill. App. 2d 547, 154 N.E.2d 862 (1958). The ensuing trial resulted in a verdict for the defendant. The appellate court again reversed and remanded, this time on the ground, inter alia, that errors in the admission and exclusion of evidence entitled plaintiff to a new trial. 28 Ill. App. 2d 300, 171 N.E.2d 432 (1960). Defendant filed a motion with accompanying affidavit pursuant to $\S 75(2)$ (c) of the Civil Practice Act which was denied by the appellate court. It then filed a petition in the supreme court for an ancillary writ of mandamus and leave to appeal. The court granted the writ and ordered the appellate court to strike the remand provision of its decree. In reinstating the original trial court decision dismissing the complaint for failure to state a cause of action, the court held that the provisions of section $75(2)(c)$ were available to defendants as well as to plaintiffs. Two justices dissented on the ground that the defendant failed to present a final order and therefore leave to appeal had been improvidently granted.

3 Bowman v. Illinois Cent. R.R., 11 Ill. 2d 186, 197, 142 N.E.2d 104, 112, cert. denied, 355 U.S. 837 (1957).

4 Wright v. Risser, 378 Ill. 72, 37 N.E.2d 778 (1942) (judgment reversing and remanding a cause not a final order). 
hearing before the supreme court. 5 After the remand is stricken, an appealable judgment of reversal remains.

If this route were unavailable, a supreme court determination would have to be preceded by a new trial and a second hearing before the appellate court. The trial court would presumably rule in accordance with the first appellate court decision; this ruling would then be affirmed by the appellate court.

In the case of a plaintiff whose trial court verdict is reversed and remanded in the appellate court, the use of section $75(2)$ (c) presents no difficulty. For example, plaintiff $A$ wins a judgment in the trial court. The appellate court reverses and remands on the basis of improper evidence introduced by $A$. A realizes that his case fails without the contested evidence. Rather than undertake a new trial, with the resulting costs and with no chance to win, $\mathrm{A}$ moves to strike the remand portion of the judgment and waives his right to a new trial, leaving only a final order of reversal. He then moves for leave to appeal to the supreme court. If the court grants leave and affirms the appellate court decision that the evidence is inadmissible, $\mathrm{A}$ has lost, but he has not been required to undergo an unnecessary trial and appeal before obtaining a hearing before the highest court. If the supreme court reverses the appellate court, the trial court judgment is reinstated. 6 Of course, if the high court should refuse to grant leave to appeal, then the final order of the appellate court remains. 7

Although the wording of the statute appears to make the election equally available to plaintiffs and defendants, the procedural device as presented in the statute had, until John $v$. Tribune Co.,8 been exclusively used by plaintiffs. 9 The appeal under section 75(2)(c) in John $v$. Tribune, however, seemed to require a full interpretation of the statute as applied to defendants who seek its benefits. Instead, the court, in deciding that the section was applicable to the defendant and then reinstating the trial court's decision, chose to postpone resolutions of the problems which are inherent in such a determination.

The inadequacy of helpful precedent and the peculiar problems arising from the use of the provision by a defendant indicate the need to consider the pos-

5 People v. McArdle, 370 Ill. 513, 19 N.E.2d 328 (1939) (supreme court has jurisdiction to review only final judgments of the appellate courts); Cowen v. Harding Hotel Co., 396 Ill. 470,72 N.E.2d 177 (1947). The wisdom of this widely-recognized rule is discussed in Crick, The Final Judgment Rule as a Basis for Appeal, 41 Y.:LE L.J. 539 (1931); Note, 47 Colum. L. Rev. 240 (1947).

6 Conner v. Borland-Grannis Co., 294 Jll. 58, 128 N.E. 317 (1920); 2 FREEMAN, JUDGMENTS 2417 (5th ed. 1925).

7 Bowman v. Illinois Cent. R.R., 11 Ill. 2d 186, 142 N.E.2d 104, cert. denied, 355 U.S 837 (1957).

8 Civil No. 36450, Ill. Sup. Ct., Jan. 23, 1962.

9 E.g., Bowman v. Illinois Cent. R.R., 11 Ill. 2d 186, 142 N.E.2d 104, cert. denied, 355 U.S. 837 (1957); Robinson v. Workman, 9 III. 2d 420, 137 N.E.2d 804 (1956); Lees v. Chicago \& N.W. Ry., 409 Ill. 536, 100 N.E.2d 653 (1951); Mabee v. Sutliff \& Case Co., $404 \mathrm{III}$. 27, 88 N.E.2d 12 (1949); Devine v. Pfaelzer, 277 Ill. 255, 115 N.E. 126 (1917). 
sible application of the statute in this situation in light of its avowed purpose. This discussion, therefore, will consider the general background and specific application of the provision in an attempt to determine the interpretation that would most closely comply with the purpose of the legislation and to explore possible legislative modifications that might increase its effectiveness when used by defendants.

A predecessor of section 75(2)(c) was adopted in 1907.10 The section was held unconstitutional in Hayward $v$. Sencenbaugh ${ }^{11}$ on the ground that the provision gave the court power to render a final judgment against one party while not against the other ${ }^{12}$ and was thus class legislation since it placed the parties on unequal footing in bringing an appeal. The current section appears to avoid the Hayward problem by requiring that the remand provision in the appellate court judgment be stricken, thus making the decision appealed from a final one. 13

After the Hayward case, enterprising lawyers conceived the method of rendering final an otherwise interlocutory order by moving to strike a remand, thus waiving the right to a new trial, on the ground that their clients could adduce no new evidence in another trial. Disposition of such motions was left solely to the discretion of the appellate court. If granted by the appellate court, the motion to strike the remandment portion of the judgment left a final appealable order. ${ }^{14}$ This made possible an immediate hearing before the

10 ILL. REV. STAT. ch. 110, $\$ 119$ (1908). It provided, in part, "And appeals shall also be allowed from the judgment of the Appellate Court to the Supreme Court, in all cases where such judgment of the Appellate Court is that the judgment of the trial court be reversed and the case remanded for a new trial, if the party so appealing will stipulate in writing, at the time of praying the appeal, that final judgment in the case may be entered in the Supreme Court against him if such appeal is not prosecuted with effect." 305.

11235 III. 580, 85 N.E. 939 (1908). The section was repealed in 1909. ILI. LAws 1909, at

12 The court's interpretation of its lack of power to render a final judgment against the party who had won a reversal in the appellate court and had not signed the stipulation required of the reversed litigant is at best confusing and strained. The court mentions that if it were to reverse the appellate court decision it would be forced either to remand the cause to the trial court or to affirm the trial court judgment. Id. at 582,85 N.E. at 940 . Why the court would find it necessary to remand to the trial court is not apparent since its only function was to decide whether the appellate court was correct in reversing the trial court for alleged errors. If the appellate court was correct, the case was resolved by the appellant's stipulation allowing a final judgment against him by the supreme court. Conversely, if the supreme court reversed the appellate court, it was saying that the trial court was correct. Therefore an affirmation of the trial court's verdict was proper. Such an affirmation was a final judgment. See Blanchard v. Lewis, 414 Ill. 515, 112 N.E.2d 167 (1953), where the defendant had signed a stipulation which was incorporated into the appellate court decree, thus making it a final order prior to the supreme court determination. The decision of the court was to reverse the appellate court and to affirm the judgment of the trial court.

13 This makes the judgment final, at least with regard to a plaintiff whose judgment has been reversed.

14 Such an appeal is not a matter of right; but leave to appeal must be granted by the supreme court. Ill. REv. SraT. ch. 110, § 75(2)(c) (1959). 
supreme court on the ruling reversed by the appellate court. This method of making final those orders which would otherwise be interlocutory was accepted by the courts for many years ${ }^{15}$ and was finally codified in section $75(2)(c) .16$

The problem inherent in a defendant's use of the section is revealed by examining the effect of his waiver on the posture of the case. The consequences to a defendant differ substantially from those that result when a plaintiff waives remand. In the plaintiff's case, the action is completed if the supreme court decides against him. A supreme court affirmance against a defendant, however, does not conclude the litigation. ${ }^{17}$

In John $v$. Tribune the second appellate court reversal and remand was based on errors in the admission and exclusion of evidence in the trial court. Upon striking the remandment, only a reversal order remained. If, instead of reversing, the supreme court had affirmed the appellate court, the plaintiff would surely have sought a new trial. The reversal of the trial court verdict for the defendant gives the plaintiff neither a verdict nor a money judgment. In the John case, the court relied on the explicit words of the statute to apply the benefits to "any party in whose favor the trial court's judgment was rendered. . .."18 But a plaintiff-user must waive his valuable right to a new

15 Devine v. Pfaelzer, 277 Ill. 255, 115 N.E. 126 (1917).

16 The practice of making final an otherwise interlocutory decree by striking the remandment was codified in the 1941 amendment to $\$ 75.2$ ILL. LAws 1941, at 467.

${ }_{17}$ In John $v$. Tribune the court specifically refused to treat this problem. "Since jurisdiction exists pursuant to 75(2)(c) and the trial court must be affirmed, no question of the consequence of an affirmance of the Appellate Court ... is reached." Civil No. 36450, Ill. Sup. Ct., Jan. 23, 1962. The benefits arising from a decision on the merits in this particular situation may explain the majority's decision to postpone dealing with those problems which may result in the section's being inapplicable to defendants. In describing such benefits of section 75(2)(c) in the circumstances of the John case, the court said: "On the first appeal . . the Appellate Court erroneously held that whether the defendant's articles were subject to the construction claimed by plaintiff . . . was one of fact rather than law. After remandment, trial, verdict, and judgment for defendant the Appellate Court again held in effect that the complaint stated a cause of action. It is reasonable to assume that a second trial ... would prompt a third appeal and possibly another remand. The parties could remain on such a treadmill indefinitely through any number ... of remandments by the Appellate Court. [The] case might never be reviewed by this court . . . until a judgment is entered in the trial court which is not reversed or remanded. ... Only then could we stop the fruitless cycle by a determination that the complaint upon which the numerous trials were predicated never stated a cause of action." Id. The reduction in fruitless litigation achieved in John v. Tribune may well result in an increase in such litigation in the supreme court because of the interlocutory nature of defendant appeals under section $75(2)$ (c). See note 24 infra.

The court could have reached, in effect, the same substantive result and at the same time dealt fully with the problems raised by a defendant's use of the section. This could have been accomplished even if it reached the conclusions that the section is not available in its present form to such applicants. It is not unknown for a court to manifest its opinion on the merits while ruling that it lacks jurisdiction. Marbury v. Madison, 5 U.S. (1 Cranch) 137 (1803). Cf. Wood v. Broom, 287 U.S. 1 (1932).

18 JlL. Rev. Stat. ch. 110, § 75(2)(c) (1959) (Emphasis added.) 
trial, 19 while a defendant-user is required to surrender no substantial equivalent.

In addition to waiving a new trial, the defendant has sworn that he will be unable "to adduce other or additional evidence, facts or circumstances than were adduced in the trial court. ..."20 Should the supreme court affirm the appellate court, the net effect of the affidavit could be rendered meaningless in the new trial demanded by the plaintiff. For example, a literal interpretation of the statutory terms would seem to require that even if the plaintiff introduces wholly new evidence, the defendant is bound not to add to his evidence presented in the original trial. Such an interpretation, however, is improbable. Also the testimony of the defendant's witnesses would appear to be confined by the contents of the first trial.21 The means of effecting such a restriction during a second trial, however, are likewise unclear. Unless a solution to such difficulties can be devised, the defendant's affidavit will be totally ineffective.

It is conceivable, in light of the interpretation in John v. Tribune, that every defendant whose verdict has been reversed in the appellate court will seek leave to appeal under section $75(2)$ (c), since he can, in reality, lose nothing, while gaining an opportunity to have his original verdict reinstated by the supreme court. Thus the net effect is to allow an interlocutory appeal to the defendant by means of a fictitious "final" order of reversal.

The rule that only final orders are appealable 22 is not without exception. ${ }^{23}$

39 The value of a new trial to the plaintiff would appear to be negligible since he has signed an affidavit stating that he has no additional evidence to adduce. However, the supreme court in Bowman seemed to suggest that the clause is used only as a formal reason for waiving a new trial. The court discusses the risk that a plaintiff-user is taking by giving up a trial. "in which more evidence may be offered and those errors of law which deprive plaintiff of her judgment may be corrected. ..." This statement is particularly curious since the court had previously discussed the terms of the affidavit. 11 IIl. $2 \mathrm{~d}$ at 193, 104 N.E.2d at 110 .

Such treatment of the affidavit results in no problems when a plaintiff is the applicant since there is no possibility of a new trial occurring. A defendant's use which will result in another trial if the court affirms the appellate decision will bring the affidavit's terms into prominence. See text at note 18 supra.

20 ILL. REV. STAT. ch. 110, §75(2)(c) (1959).

21 It does not seem likely, despite the fears expressed by the defendant in John v. Tribune, that the defense witnesses would be forced to repeat the exact words used in the prior trial. Brief for Appellants in Support of Motion for Mandamus, p. 8.

22 Appellate courts hold firm to the final order doctrine in order to eliminate piecemeal appeals which could cause useless delay in the judicial process. A final decision will at least end the complaints of the winning litigant about the court's errors adverse to him, and as to his opponent, no more errors will present themselves which would result in additional interlocutory appeals. Roberts v. Stagg, 1 Nott \& Mc. 429 (S.C. 1819). On the other hand, if certain appeals were allowed, prior to the final judgment, on the validity of doubtful decisions by the lower court, much litigation could be avoided in the event the appellate court were to hold such decisions to be error. See Crick, supra note 5, at 558, where the suggestion is made that instead of arguing whether a decision is final or not, the question should be 
There are several instances in which purely interlocutory decrees are treated as final in order to allow immediate appeals. ${ }^{24} \mathrm{~A} 1958$ amendment 25 has enabled the federal system to allow interlocutory appeals to a court of appeals in certain cases not otherwise appealable. The amendment makes the motion for such appeal wholly dependent upon the discretion of first the district judge and then the appellate court. The purpose of the federal provision is much the same as that of section $75(2)$ (c): to avoid protracted and expensive litigation which may be needless because based on incorrect law. ${ }^{26}$ The element of discretion involved in the supreme court's determination of whether to grant leave to appeal is similar to that of the federal courts of appeal. This would seem to indicate that even though the defendant has in reality only an interlocutory decree, the supreme court will choose, as it did in John v. Tribune, to recognize his eligibility to appeal. There are factors, however, which indicate that the statutory provisions are not directly analogous. While other statutes 27 allow interlocutcry appeals to the first level of appellate courts, none allows such appeals to the highest court in the jurisdiction. Also, the two Illinois statutes 28 which permit certain interlocutory appeals specify that the judgment of the appellate court is not reviewable. Finally, despite the check on the number and kinds of appeals supplied by the thoughtful exercise of supreme court discretion, the court has already expressed an unwillingness to hear cases where there has been no final judgment:

whether this is the sort of decision which the appellate court wishes to hear. This suggestion is carried out to a limited extent by the federal, Iowa, and Minnesota statutes. See note 25 infra.

23 The rule has been modified by statute to allow certain types of interlocutory appeals. ILL. REV. STAT. ch. 110, \& 78 (1959) (appeal from interlocutory order granting, modifying, refusing, dissolving or refusing to dissolve or modify an injunction, or appointing or refusing to appoint, or giving or refusing to give additional powers to a receiver). See also, e.g., Cal. Civ. Proc. Code §963; TfX. Rev. Civ. Stat. art. 2250 (1948).

24 ILI. REv. Stat. ch. 110, § 77 (1959); Kavenaugh v. Washburn, 387 IIl. 204, 56 N.E.2d 420 (1944). (the word "final" applied to order granting a new trial and used in the sense of being appealable); Liebbrand v. Butler, 88 Ohio App. 185, 97 N.E.2d 80 (1950) (order granting a new trial a final order from which appeal may be taken).

2528 U.S.C. $\S 1292$ (b) (1958): "When a district judge, in making in a civil action an order not otherwise appealable under this section, shall be of the opinion that such order involves a controlling question of law as to which there is substantial ground for difference of opinion and that an immediate appeal from the order may materially advance the ultimate termination of the litigation, he shall so state in writing in such order. The Court of Appeals may thereupon, in its discretion, permit an appeal . . from such order. ..." (Emphasis added.) For similar discretionary interlocutory appeals see IowA R. CIv. P. $\S 332$ (1958); MINN. STAT. $\$ 605.09(4)$ (1957).

26 H.R. Rep. No. 1667, 85th Cong., 2d Sess. 1, 2 (1958).

2728 U.S.C. §1292(a) (1958) limits interlocutory appeals to certain cases involving (1) injunctions, (2) receiverships, (3) admiralty, and (4) patents which are final except for accounting.

28 ILl. Rev. StAt. ch. 110, $\$ \S 77,78$ (1959). 
The second element necessary to come under paragraph (2)(c) is that the affidavit of the party who won the case below, and whose case has been reversed and remanded, will present a question upon which the Appellate Court can render a final judgment, because in no event can an appeal be taken from the Appellate to the Supreme Court unless the judgment is final. ...29

This emphasis on finality, asserted again in Bowman v. Illinois Cent. R.R., ${ }^{30}$ was disregarded by the majority in John $v$. Tribune, ${ }^{31}$ where the court noted that the Illinois constitution confers jurisdiction on the supreme court "in such other cases as may be provided by law." 32 Since section 75(2)(c) authorized an appeal in the circumstances of the John case, the result is an interlocutory appeal from a judgment under a statute designed to make final just such judgments. It is doubtful that such a result was the intention of the legislature in enacting the section. No other provision of the Civil Practice Act allows interlocutory appeals to the supreme court. ${ }^{33}$

The extent of applicability is further clouded by the court's recent discussion of the right of plaintiffs to use the device in certain cases. A dictum in Lees v. Chicago \& N.W. Ry., ${ }^{34}$ two justices dissenting, would limit the section's use to cases where the cause is reversed and remanded for insufficient evidence. This doctrine was specifically rejected in the Bowman case ${ }^{35}$ with three justices dissenting. The court said:

A careful reading of section 75(2)(c) reveals that by its terms it does not limit the right to strike the remanding order to cases where the Appellate Court reverses for insufficient evidence, or for any other particular grounds. The statute is all encompassing, and grants the right to strike the remanding portion of the order in all cases where the Appellate Court reverses and remands a cause for a new trial, provided the party in whose favor judgment was originally entered in the trial court files the requisite affidavit. ... .36

The court then enumerated cases, 37 decided under both the statute and its common law equivalent, where appeals were allowed when trial errors other

29 Lees v. Chicago \& N.W. Ry., 409 III. 536, 542, 100 N.E.2d 653, 656 (1951). (Emphasis added.)

3011 Ill. 2d 186, 189, 142 N.E.2d 104, 108, cert. denied, 355 U.S. 837 (1957). See Olson v. Chicago Transit Authority, 1 Ill. 2d 83, 87, 115 N.E.2d 301, 304 (1953) (final judgment rule embodied in more than a century of common and statutory law in Illinois).

31 Civil No. 36450, Ill. Sup. Ct., Jan. 23, 1962.

32 Ill. Const. art. VI, $\S 11$.

33 See statutes cited note 28 supra.

34409 III. 536, 543, 100 N.E.2d 653, 657 (1951).

3511 Ill. 2d 186, 142 N.E.2d 104, cert. denied, 355 U.S. 837 (1957).

${ }^{36} \mathrm{Id}$. at 192-93, 142 N.E.2d at 110 . (All italicized in original.)

37 Id. at 195, 142 N.E.2d at 111; Hartley v. Red Ball Transit Co., 344 III. 534, 176 N.E. 751 (1931) (errors in submission of evidence); Blanchard v. Lewis, 414 Ill. 515, 112 N.E.2d 157 (1953). 
than insufficiency of evidence had occurred. Prior to codification in section $75(2)$ (c), the question of whether or not to strike the remanding portion of a judgment in order to grant the reversed party leave to appeal was a matter for the appellate court's discretion. ${ }^{38}$ Section $75(2)$ (c), of course, makes striking mandatory upon the appellate court in all cases where the reversed party files the proper motion and affidavit. 39 The dissenters argued that in cases where a new trial is ordered because of numerous errors which deprive the party of a fair trial the appellate court is not obligated to strike the remandment. 40 The closeness of the vote on the mandatory nature of section 75(2)(c) indicates further difficulty for a defendant attempting to use the section upon the basis of an illusory final order.

There is no constitutional problem involved in allowing the plaintiff to use section $75(2)$ (c) while not allowing the defendant to do so.41 Two cases, decided prior to John v. Tribune, indicate that, despite the absence of a constitutional requirement that the statute applies to defendants as well as plaintiffs, and despite the described difficulties, the section is available to defendants in its present form. In Reilly Tar \& Chem. Corp. v. Lewis, ${ }^{42}$ plaintiff sued upon a contract and defendant won a directed verdict. The appellate court reversed and remanded.43 The second trial brought a jury verdict for the defendant; again the appellate court reversed and remanded.44 The third trial again found the jury holding for the defendant. Reversing and remanding for the third time, the court said, "Should defendant desire to avail himself of the above provision, he should file a motion and affidavit in accordance with the paragraph quoted from sec. 75 of the Civil Practice Act." 45 The defendant, however, failed to file the necessary motion and affidavit. The issue was thus never posed for adjudication.

38 Jenner \& Tone, Historical and Practice Notes, ILL. ANN. STAT. ch. 110, 875 (SmithHurd 1956.

39 Bowman v. Illinois Cent. R.R., 11 Ill. 2d 186, 197, 142 N.E.2d 104, 109, cert. denied, 355 U.S. 837 (1957).

${ }^{40} \mathrm{Id}$. at 216, 142 N.E.2d at 122. (Schaefer, Hershey, and Davis, J. J.)

41 The Supreme Court has specifically overruled the Hayward case, see note 11, supra, "to the extent that it may be thought to hold that review by this court may not be conditioned upon the appellant's willingness to forego a new trial and thus make final the judgment of the Appellate Court. We have upheld a statute giving a right of appeal to the defendant from an interlocutory decree appointing a receiver or granting an injunction while denying the plaintiff an appeal from an order refusing to grant the same relief. . . . A classification based upon the finality of the judgment sought to be reviewed is no less reasonable than that sustained in those cases." Olson v. Chicago Transit Authority, 1 Ill. 2d 83, 89, 115 115 N.E.2d 301, 305 (1953) (Emphasis is added.)

42326 Ill. App. 117, 61 N.E.2d 297 (1945) (errors in admission of evidence).

43301 Ill. App. 459, 23 N.E.2d 243 (1939) (plaintiff's evidence presented prima facie case).

44326 Ill. App. 84, 61 N.E.2d 290 (1945) (numerous trial errors).

45326 Ill. App. at 134, 61 N.E.2d at 304 (after quoting $\S 75(2)$ (c)). 
In Blanchard v. Lewis, 46 defendant used the section but not according to its literal terms, for he filed a stipulation, incorporated into the appellate court decree, as to liability for an exact amount of damages. ${ }^{47}$ Such stipulation is not required by the words of the statute, 48 but the case does indicate that the supreme court had not assumed an inflexible position against a defendant using section $75(2)$ (c). This stipulation placed the defendart in the same category as a plaintiff-user of the section in that the possibility of a new trial was avoided by the agreement as to liability and damages inserted into the appellate court's order of reversal. A new trial would not be necessary even if the supreme court should affirm the appellate court's reversal of defendant's verdict. 49

The dissent in John $v$. Tribune ${ }^{50}$ sugzests another possible interpretation of the section. The dissenters' objection to jurisdiction was based on the alleged failure of the defendant to fulfill the statutory requirement of an express waiver of the right to a new trial or hearing. The defendant's affidavit stated that while it waived its right to a new trial, nothing contained therein was a consent to the entry of any money judgment against it. In basing their objection on this clause, the dissenters imply that the defendant's waiver of a new trial should be construed as a consent to a judgment of liability for the full amount of plaintiff's claim if the appellate court's reversal is affirmed. This interpretation would result in a truly final order being appealed and at the same time could cause the waiver of the new trial under the remandment to have the same effect on the defendant as on the plaintiff under the section. By requiring effective waiver, the court would restrict the number of requests for leave to appeal to those which the parties believe to be important enough to exchange for their right to a new trial. Despite the possible value of such restriction, there is no precedent for implying a consent requirement under section 75(2)(c).

A means of resolving the problems raised by a defendant's use of section $75(2)(c)$ is suggested by the New York statute allowing appeals from an order

46414 III. 515, 112 N.E.2d 167 (1953). A fear that the court would construe the statute as inapplicable to defendants may have been the reason for defendant's stipulation with regard to liability and damages. The stipulation was incorporated into the appellate court's judgment so that if the supreme court affirmed, the case would be resolved as to all parties. The action was upon a contract and the damage amount was evidently not an issue since the stipulation was for the odd amount of $\$ 52,154.63$. The supreme court in Bowman erroneously treats the Blanchard case as if it were the plaintiff whose verdict was reversed.

47 Record, pp. 145-46.

48 The effect of the stipulation, signed by both litigants, as to liability for a set amount of damages is discussed in text at note 55 infra.

49 Since the stipulation was wholly voluntary, the problems raised by defendant's use of the section have never been considered by the court.

so Civil No. 36450, Ill. Sup. Ct., Jan. 23, 1962 (Schaefer and Hershey, J. J.). 
granting a new trial.51 An appellant from such order must stipulate that upon affirmance he consents to a final judgment against him. 52 The provision is intended to aid those litigants who prevailed at the trial and who are satisfied to have that verdict sustained or fail altogether in their action or defense.53 If the first appellate decision is affirmed, the judgment in the New York Court of Appeals is thus founded solely upon the consent of the party making the stipulation. 54 The stipulation means that affirmance will result in damages to the full extent of the plaintiff's complaint. 55

Amending section 75(2)(c) to contain a stipulation clause similar to the one voluntarily used in the Blanchard case will allow defendants to use the statute, but not without the same risks as plaintiff-users. By incorporating the stipulation into the appellate court's order, there can be no doubt as to the finality of the order. Such an amendment would limit the availability of section $75(2)$ (c) to those cases where it would be most useful: when a litigant's whole defense has been ruled out by the appellate court. In fact, the stipulation requirement would further limit its use to cases in which the damages are liquidated or a settlement as to damages is reached prior to entering the stipulation and waiver affidavit. That this would drastically reduce the number of defendant appeals under section 75(2)(c) is not necessarily an undesirable result if it is assumed that only those cases which can be finally determined by a supreme court decision are proper subjects for the section's benefits.

The supreme court in future cases interpreting section $75(2)(\mathrm{c})$ has various alternatives from which to choose. The court can decide, as it did in John v. Tribune, that defendants can have what amounts to an interlocutory appeal, since such party's waiver of a new trial is a mere fiction, and depend upon the court's discretionary powers under the leave to appeal doctrine to limit the application of the section to only important cases. Alternatively, the court can cling to the traditional doctrine of finality in appealable decrees and thus render the statute inapplicable to defendants. Such a holding, however, would ignore the professed aim of the legislation since the laudable purpose of reducing litigation costs and unnecessary delay is no less praiseworthy when applied to a defendant. 56 The two further possibilities involve a somewhat

51 N.Y. Crv. PrAC. Acr. § 588: “Appeal to Court of Appeals as of right lies only, (3) from an order of the Appellate Division granting .... or affirming .... a new trial or hearing in an action ... commenced in the Supreme Court, a county court, ... court of claims ... . where the appellant stipulates that upon affirmance, judgment or order absolute shall be rendered against him; and upon such appeal the court of appeals shall affirm and render judgment or order absolute against the appellant unless it determines that the Appellate Division erred as a matter of law...."

52 United.Sec. Corp. v. Suchman, 307 N.Y. 48, 119 N.E.2d 881 (1954).

53 Lanman v. Lewiston R.R., 18 N.Y. 493 (1859).

54 Canfield v. Elmer E. Harris \& Co., 252 N.Y. 502, 170 N.E. 121 (1930).

ss City Trust, S.D. \& S. Co. v. American Brewing Co., 182 N.Y. 285, 74 N.F. 948 (1905),

56 See note 17 supra and text accompanying note 45 supra. 
forced construction of the present terms of the section or an actual legislative enactment to require consent to liability and damages in order to make the benefits of the section available solely to a limited number of defendants who are willing to risk their chances of regaining their verdict at a new trial on the probability of a supreme court reversal of the appellate court decision. The conflicting precedents, which on one hand suggest that defendants may avail themselves of the section, 57 while on the other hand place emphasis on the necessity for a final appealable decree in order to use section 75(2)(c), ${ }^{58}$ make the ultimate interpretation by the supreme court unclear. Effective use of the provision by practitioners as well as a reasonable evaluation of the present statute and a rational consideration of possible modification can be achieved only if based upon a definitive statement of the applicability of section $75(2)(c)$.

57 John v. Tribune Co., No. 36450, Ill. Sup. Ct., Jan. 23, 1962; Reilly Tar \& Chem. Corp. v. Lewis, 326 Ill. App. 117, 61 N.E.2d 297 (1945).

58 Bowman v. Illinois Cent. R.R., 11 Ill. 2d 186, 142 N.E.2d 104, cert. denied, 355 U.S. 837 (1957); Lees v. Chicago \& N.W. Ry., 409 Ill. 536, 100 N.E.2d 653 (1951). 